\title{
THE USE OF MULTILITERATION MODEL TO IMPROVE MATHEMATICAL CONNECTION ABILITY OF PRIMARY SCHOOL ON GEOMETRY
}

\author{
Zaenal Abidin ${ }^{1 *}$, Al Jupri ${ }^{2}$ \\ ${ }^{1}$ S.Pd., Universitas Pendidikan Indonesia, INDONESIA, zaenalabidin@student.upi.edu \\ ${ }^{2}$ S.Pd., M.Sc., Ph.D, Universitas Pendidikan Indonesia, INDONESIA, aljupri@upi.edu \\ ${ }^{*}$ Corresponding author
}

\begin{abstract}
The data of Trends in International Mathematics and Science Study (TIMSS) in 2015 has shown that the primary students in Indonesia have the $6^{\text {th }}$ lowest skill. This is occurred as the students have not been facilitated by connection skill to improve their standard one. Mathematics learning activity can be used to improve the connection skill for it has a systematic and connection concepts affecting to their good attitude and logical systematic and rational thinking. Therefore, teachers should be able to choose a learning model to improve mathematical connection skill of the students. One of which is by using Multiliteration learning model. Multiliteration learning model consists of four learning stages including setup, explore, discuss, presenting . The research aims to determine student's mathematical connection skill between learning using Multiliteration and conventional model. This used a quasi-experimental research with non-equivalent control group design. The research had been examined in Primary School. The material taken in the research is Geometry in Theme 7 Curriculum 2013. Based on data processing of connection skill test, the average pretest results of control group is 28,3 and experimental group is 27,7. After receiving different treatment, the average posttest result of control group is 63,3 and experimental group is 86,3 . Improvement quality of student's mathematical connection of experimental group is higher than control group, which is in medium. Thus, Multiliteration learning model can be used as one of the alternative learning model to improve the student's mathematical connection.
\end{abstract}

Keywords: Multiliteration learning model, Mathematical connection, Conventional model, Geometry, Primary school student.

\section{INTRODUCTION}

The development of science and technology in the 21st century has required every individual to think critically, systematically, logically, creatively, and well interacted with society. Trilling and Fadel (2009) state that education in the 21 st century emphasizes four learning competencies that must be mastered by students, namely high comprehension, critical thinking, collaborative, and the communicated skills. 
In contrast to the competence standard in the 21st century, the competence of Indonesian students is still bad. This can be seen in the results of Trends of International Mathematics and Science Study (TIMSS) in 2015 that Indonesia is in the 45th of 50 countries. This shows that children in Indonesia who are in primary school are still lacking in the ability of Mathematics.

The results of observation in primary school shows that learning mathematics is very difficult to be associated with other materials or subjects. This is caused by teacher's unfamiliarity to teach math. Meanwhile, as we know that the standard of the Curriculum 2013 must have the existence of connection between one subject with another one, known as Tematic Integrated. In addition, the students also feel confused when they learn math with no separation. This is occured since the students have not yet been facilitated to develop their connection skills, especially in the students' mathematical connection ability.

Mathematical learning can develop the attitudes and ways of thinking that become the demand of the science development in the 21 st century as it has a systematic learning concept. Therefore, it will be demanded a regularity in every concept, and there is also a linkage to each concept that can not be separated. It will have an impact on a logical, systematic, and rational attitude and their way of thinking.

In line with the discussion, in the National Council Teachers of Mathematics (NCTM, 2012) mentioned that there are five basic mathematical standards. They are problem solving, reasoning and proofing, communication, connections, and representation. This is also related to Triling \& Fadel's opinion (2009, p 48) which explains that skills in the 21st century are the learning skills of innovating and contextually problemsolving.

In the relation to assigned mathematics competencies, primary school students should have good mathematical connection skills in order to master the mathematical concepts of one material with other materials, to solve problems related to mathematics, and to appreciate mathematics in a real-life context. In addition, a learning system should deliver information received by students into long time memory, so students will never forget things that have been taught. For good learning is a meaningful one that can always be reminded by the students whenever they are. The explanation is in accordance with the explanation of the Ausubel learning theory (in Suwangsih \& Tiurlina, 2006 p.74) that learning activities must be meaningful, students understand the concept or material by linking information or subject matter on the cognitive structure they have.

Ausubel, Bruner (in Suwangsih \& Tiurlina, 2006 p. 86) explains "In mathematics, every concept is related to another concept. Neither with others, such as theorem and theorem, between theory and theory, between topics and topics ". It is increasingly asserted that a learning should facilitate students to always see the linkage between one component with other components. In this case, it is clear that students should be facilitated to develop and optimize the ability of mathematical connections.

In line with the above statement, there are two common types of mathematical connections according to NCTM (2000), Modeling Connections and Mathematical Connections. Modeling Connections is the relationship between real-world problem situations with a representation of media / modeling, while Mathematical Connections is the relationship between mathematical material with other ones or with other subject matter.

To solve these problems, it is clear that learning should have a representative medium that can connect between students' knowledge in real situations and learning materials. In addition, there should be a model that can develop old and new knowledge of students and facilitate their mathematical connection ability. In order to fulfill all competencies, a teacher should be able to become a facilitator and mediator in meeting the needs of students related to 21 st century competence. Therefore, teachers should be able to choose the right learning model to meet their competencies.

In the learning process, teachers play an important role in facilitating students. Teaching method that teachers use can not be separated from the learning model that they use. The learning model is a plan used to shape the curriculum, making learning materials, and becoming a learning guide (Joyce, Weil, \& Calhoun, 2009). Furthermore the model is translated into a broad unity of learning systems that contain a special philosophical basis or a pedagogic learning theory (Bhargava, 2016). So, the learning model is a conceptual framework used in a lesson.

As the development of learning in the 21st century, the model of learning used by teachers is also develpoing. In bridging the competence to be mastered by students, teachers are required to use learning models that can facilitate students to think critically, creatively, and innovatively. The success of students in learning is not only measured by how much they remind the material given by the teacher, but how students understand the concept that has been given by the teacher. There is a significant difference between 
reminding and understanding. In Bloom's taxonomy known as Taxonomy of Learning (Trilling \& Fadel, 2009), the reminding is in phase $\mathrm{C} 1$, that is basic ability in the cognitive domain. While the understanding is in phase C2, which is a higher step than reminding. To enable students to understand the concept provided by the teacher, it is required learing model that can support it.

Constructivists view that meaningful learning is the thing that can make students discover their own concepts, in accordance with the opinions of Glaserfeld and Matthews (in Siregar and Nara, 2010). The teacher's role is a facilitator in the process of discovery of the concept. The concept is a tool that human beings use to organize infinite impressions using their five senses (Swidler, 2014). When students have been able to build their own concepts, the teaching materials given will be understood by students. One of the learning models that gives students the opportunity to build their own concepts is the Multiliteration Model.

The research on integrated literacy model with mathematics has been done by Shyyan (2008). Shyyan (2008) explains that reading which is integrated with mathematics has been able to develop the ability of teachers in generating a number of learning strategies and simultaneously improve the ability of students in mastering mathematical concepts. In line with the research by Shyyan, Olge et al (2007) explains that multiliterational learning can link learned material to already known material of the students and link the material learned with real life and contemporary issues.

From all the above descriptions, there has been no research focusing on Multiliteration Modell Learning in Primary Schools in Mathematics subjects focused on mathematical connection ability. Therefore, in this research, I will examine " The Use Of Multiliteration Model To Improve Mathematical Connection Ability Of Primary School Students".

\subsection{Multiliteration Model}

Morocco, et al. $(2008, \mathrm{p} 10)$ states that the multiliteration skills which must be mastered in order to support and develop the four competencies of the 21 st century include high-level reading and good writing skill to build and express meaning, accountably speaking and mastering skill in the various digital media. These four skills show that the mastery of any literacy can not be separated from the concept of literacy in the dimensions of the field of language skills. The importance of high reading skills is further expressed by Concannon-Gibney and McCarthy (2012) which states that "... all students should be provided with the problem of solving, communication and thinking skills that they need to be effective worker and citizen in the 21st century. Reading plays a key role in science achievement. "

McConachi, et al. (2010) provides the term disciplinary literature to describe multiliteration learning models. Based on his opinion, disciplinary literacy learning is a learning that emphasizes the use of reading, logic, research, speaking and writing to study and form a complex understanding of the knowledge content associated with a particular field of knowledge. This opinion is in line with Ivanic (2009) which states that multiliterational learning is a learning challenge for students to study and apply practical literacy that serves as a mediating tool to learn cross-curriculum concepts.

The concept of multiliteration learning is also expressed by other experts namely McKee and Ogle (2005). Mckee and Ogle (2005) provide insight into multiliterational learning, literacy should initially be viewed as the ability to use reading, writing, listening and speaking as efficiently as possible to improve thinking and communication skills.

In line with the above description, the multiliteration learning model can be defined as a learning model that optimizes multiliteration skills in realizing scientific learning process situations. This learning is oriented to the development and the use of 21 st century of critical thinking, conceptual understanding collaborative and communicative, and creative thinking competence. The skills used to support the four competencies are reading, writing, speaking, and the mastery of information and communication media skill.

\subsubsection{Multiliteration Model Steps}

For mathematics, multiliteration learning steps are developed by Bill and Jamar (2010). Bill and Jamar (2010) explain that multiliteration learning steps are as follows:
1) Setup
2) Explore
3) Share and Discuss
4) Presenting 


\section{METHODOLOGY}

The selected population in this study is all fourth-grade students of primary school in the second semester of the academic year 2016/2017 in Cileunyi. SD Laboratorium UPI Cibiru was defined as sample by researcher. The selection of the sample was not randomly done. Samples were selected based on sampling incidental technique. Based on observations on mathematics and homeroom teachers, the obtained information confirmed that the two sampled classes have the same mathematical skill, so that the determination and control group experiments can be conducted on class IV-B and IV-C. In this study, researchers set VI-C as an experimental group and class IV-B as the control group.

This study is a quasi-experimental research. The study design that is used by the researchers is a design that has a pretest and posttest or nonequivalent control group design. Here is an overview of the quasiexperimental research design of nonequivalent control group design.

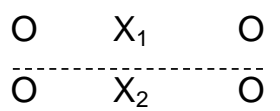

Description:

$\mathrm{O}:$ Pretest $=$ posttest $($ test connection capabilities)

$\mathrm{X} 1$ : treatment of learning using Multiliteration Model

X2: treatment conventional

---- Namely: the subject is not grouped randomly

The research instruments used in this study are test and non-test instrument. The test instrument in this study is a test that forms description to measure the skill in connecting students' mathematical, while the non-test instrument forms an observation sheet that is used to measure the activity of teachers and students in the experimental group.

\section{RESULT AND DISCUSSION}

\subsection{RESULT}

\subsubsection{The Result of Pretest}

Based on the research that has been done, the acquisitio mean score of pretest and posttest experimental group and the control group were as follow:

Table 1 Average score of pretest and posttest

\begin{tabular}{|c|c|c|}
\hline Group & Pretest & Posttest \\
\hline Experiment & 27,7 & 86,3 \\
\hline Control & 28,3 & 63,3 \\
\hline
\end{tabular}

For more details, it can be seen in the data description score pretest in Table 2 below.

Table 2. Descriptive Sratistics

\begin{tabular}{|c|c|c|c|c|}
\hline \multicolumn{5}{|c|}{ Descriptive Statistics } \\
\hline Group & $N$ & Sum & Mean & $\begin{array}{c}\text { Std. } \\
\text { Deviation }\end{array}$ \\
\hline Experiment & 30 & 832 & 27,7 & 11,974 \\
\hline Control & 30 & 848 & 28,3 & 10,017 \\
\hline
\end{tabular}

Table 2 above, it can be seen that the skill of students' initial experimental class and control class were not 
quite different. It can be seen from the average achieved scores of pretest experimental class of 27,7 and an average score of pretest 28,3 control class, overall the research class has the same mathematical connection capabilities.

Table 3 Normality Distribution Scores Pretest

\begin{tabular}{|c|r|r|r|}
\hline \multirow{2}{*}{ Group } & \multicolumn{3}{|c|}{ Kolmogorov-Smirnov } \\
\cline { 2 - 4 } & Statistic & \multicolumn{1}{c|}{ Df } & \multicolumn{1}{c|}{ Sig. } \\
\hline Experiment & .141 & 30 & .133 \\
\hline Control & .144 & 30 & .114 \\
\hline
\end{tabular}

Based on Table 3 above, it can be seen that results the output of variance test for normality using Kolmogorov-Smirnov test showed significant score data pretest for the experimental group and the control group was 0.133 is 0.114 . Due to the significant value of both groups of more than 0.05 , then $\mathrm{H}_{0}$ is accepted. It can be said that the distribution of the samples are normal.

Taking the significant stage at $\alpha=5 \%$ of decision-making criteria are $\mathrm{H}_{0}$ accepted if significance (sig. ) $\geq 0.05$, and $\mathrm{H}_{0}$ is rejected if the value of significance $(\mathrm{sig})<0.05$. After processing the data, display of output can be seen in Table 4 below.

Table 4 Homogeneity of Two Variances Score Pretest

\begin{tabular}{|r|r|}
\hline \multicolumn{2}{|c|}{ Test of Homogeneity of Variance } \\
\hline Levene Statistic & Sig. \\
\hline 2.568 & .115 \\
\hline
\end{tabular}

Based on Table 4 above, it can be seen that the level test of significance Statistic Level is above 0.05 is 0,115 . Based on the test results Levene Statistic, it can be concluded that $H_{0}$ is accepted, meaning that there is no different variance between the experimental group and the control group.

Because the normality and homogeneity tests meet the criteria for the $t$ test, then the following hypotheses are used to determine differences between the mean scores pretest the experimental group and the control group.

Table 5 Independent Samples pretest Test

\begin{tabular}{|c|c|c|}
\hline \multicolumn{3}{|c|}{ Independent Sampel Test } \\
\hline$T$ & $d f$ & Sig (2-tailed) \\
\hline-.187 & 58 & .852 \\
\hline
\end{tabular}

Based on table 5 above, it appears that $t$ for pretest with equal variance assumed probskill is -0.187 to 0.852 . Due to the acquisition of two-sided test probskill is greater than $0.05(0.852>0.05)$, then $\mathrm{H}_{0}$ is accepted. It can be assumed that the skill to mathematically connect the two groups on the pretest was not significantly different, meaning that the experimental group and the control group had the skill to connect before the two groups were treated differently.

\subsubsection{The Result of Posttest}

Posttest was performed in order to see the skill in connecting mathematical students in the experimental group and the control group after getting a different treatment. The data analyses score of posttest of the 
experimental group and the control group are presented in Table 6 below.

Tabel 6 Posttest Scores

\begin{tabular}{|c|c|c|c|c|c|c|}
\hline \multicolumn{7}{|c|}{ Descriptive Statistics } \\
\hline Group & $N$ & Minimum & Maximum & Sum & Mean & $\begin{array}{c}\text { Std. } \\
\text { Deviation }\end{array}$ \\
\hline Experiment & 30 & 68 & 100 & 2588 & 86,3 & 9,724 \\
\hline Control & 30 & 48 & 80 & 1900 & 63,3 & 9,689 \\
\hline
\end{tabular}

According to the table above, it can be seen that the minimum score in the experimental group is 68 and the maximum score is 100. Minimum score in the control group was obtained at 48 and a maximum score of 80 . Having obtained experimental group and the control group received a different treatment, it obtained an average score posttest of 86,3 experimental group and the average score of posttest control group by 63,3 . Thus it appears that the average score of posttest experimental group is greater than the average score of posttest control group by a margin of 23 .

Table 7 Normality Distribution scores posttest

\begin{tabular}{|c|r|r|r|}
\hline \multirow{2}{*}{ Group } & \multicolumn{3}{|c|}{ Kolmogorov-Smirnov } \\
\cline { 2 - 4 } & Statistic & \multicolumn{1}{|c|}{ Df } & \multicolumn{1}{c|}{ Sig. } \\
\hline Experiment & .137 & 30 & .154 \\
\hline Control & .135 & 30 & .174 \\
\hline
\end{tabular}

Based on the table above, it can be seen that results the output of variance test for normality using Kolmogorov-Smirnov test, demonstrated the significant value of the data scores of posttest for the experimental group and the control group of 0.154 and 0.174 . Due to the significant value of both groups of more than 0.05 , then $\mathrm{H}_{0}$ is accepted. It can be assumed that the distribution of data from both sample groups is normal.

Table 8 Homogeneity Two scores Variance posttest

\begin{tabular}{|r|r|r|c|}
\hline \multicolumn{4}{|c|}{ Test of Homogeneity of Variance } \\
\hline Levene Statistic & \multicolumn{1}{|c|}{$d f 1$} & $d f 2$ & Sig. \\
\hline .001 & 1 & 58 & .979 \\
\hline
\end{tabular}

According to the table above, it can be seen that the level test of significance Statistic Levene is above 0.05 is 0,979 . Based on test Levene Statistic results, it can be concluded that $\mathrm{H}_{0}$ accepted, meaning that there is no different variance between the experimental group and the control group. This indicates that there was not any different variance of the data score posttest connection mathematically to the experimental group or the control group.

Furthermore, namely $t$ test, following a hypothesis that is used to determine the differences between the mean scores posttest experimental group and the control group.

At this stage, it will be done $t$ test (Independent Sample T-test) with the assumption that the data came from a normal distributed population. The test results of mean difference the posttest two samples is presented in Table 9 below. 
IJAEDU- International E-Journal of Advances in Education, Vol. III, Issue 9, December 2017

Table 9 Posttes $t$ Independent Samples Test

\begin{tabular}{|c|c|c|c|c|c|c|}
\hline \multicolumn{7}{|c|}{ Independent Sampel Test } \\
\hline$T$ & $d f$ & Sig (2-tailed) & $\begin{array}{c}\text { Mean } \\
\text { Difference }\end{array}$ & $\begin{array}{c}\text { Std. } \\
\text { Error Difference }\end{array}$ & Lower & Upper \\
\hline 9.151 & 58 & .000 & 22.9333 & 2.50621 & 17.916 & 27.95 \\
\hline
\end{tabular}

Based table 9 above, it appears that $t$ to posttest with equal variance assumed probskill is 9.151 to 0.000 . Due to the acquisition of two-sided test probskill of less than $0.05(0.000<0.05)$ and $t$ is greater than $t$ table (5.044> 2.002), then $\mathrm{H}_{0}$ is rejected. The average score posttest experimental group and the control group was different. Additionally, according to the table above were obtained also mean difference for score posttest score of 22,9333 with an average difference of 17.916 and below the average of the top amounted to 27.95 . This may imply that the average difference of posttest ranged from 17.916 to 27.95 with an average difference amounted to 22,9333.

From all of the description above, it can be a common thread that there are differences in the skill to connect students' mathematical between groups of students experiment that uses a learning model Multiliterasi with a control group using learning usual (conventional) in the context of Curriculum 2013 that learning is always scientific.

\subsection{DISCUSSION}

\subsubsection{The Difference in Skill Connection Mathematically}

From the results of hypothesis testing in this study, there are differences in the skill to connect mathematical students skill who obtain Multiliteration model learning with mathematical connection capabilities of students who received the usual learning (Conventional).

Based on the data process that has been done before, the average score of pretest obtained for the experimental group was 27,3. Once students are treated through the Multiliteration model of learning, mathematical connection skill of students has increased significantly. It can be seen from the high average of achieved posttest scores of students that is equal to 86,3 . Thus, it can be concluded that the Multiliterasi Model learning can improve students' mathematical connection capabilities significantly.

Learning Model Mulriliterasi is able to train students' maturity through the four stages of learning. In this study, students' initial knowledge becomes the basic capabilities which will be strengthened through the activities of setup, explore, share discuss, and presenting. The learning activities in groups are able to create a good social interaction among students. With a cooperative setting, the stage of setup has made every student for having equal responsibility to understand each lesson undertaken by the group, every stages of the Multiliteration Model greatly affect the maturity of thought obtained by the students to be able in increasing the skill of students' mathematical connections.

In this Multiliteration model, student is facilitated a strengthening through the stage Presenting in an effort to improve or enrich himself on the charge of material that has already learned. Unlike the experimental class, the class of the control activities carried out only conclusion to conclude a material that has been learned and follow up on deficiencies in the learning process without facilitating the students to realize the mistakes and shortcomings. This is in line with the theory of Ausubel (in Suwangsih \& Tiurlina 2006 p.86): "In mathematics every concept associated with other concepts. Neither with others, for example, the proposition and the proposition, between theory and theory, between the topic with the topic".

\section{CONCLUSION}

Based on the results of data analysis and discussion that is proportional to focus research problems, it can be a common thread about the study of mathematics by Multiliteasi Model on the material Theme 7 Curriculum Primary school in 2013. The conclusion is There are differences in the skill of students' mathematical connection between students who obtained using Multiliterasi Model learning with students who received conventional learning. Learning math using Model Multiliterasi significantly influences the increase of students' mathematical connection capabilities. This is due to Model Multiliterasi provides opportunities and facilitates the students to see how the math materials with other mathematical material, 
material math with other subjects matter, and mathematics in the context of everyday life. So that, it impacts the skill to connect mathematical students' acknowledgment learning by Multiliterasi Model better than students who received conventional learning.

In this case, the skill to connect mathematical students learning with Multiliterasi Model and conventional learning are scientifically increased. It can be seen from index results normalized gain. Based on the criteria of the index gain, the quality of connection mathematical skill of students learning with Multiliterasi Model increases in the high category, while the quality of the connection mathematical skill of students who received conventional learning averagely increase.

\section{ACKNOWLEDGEMENT}

Special thanks to Lembaga Pengelola Dana Pendidikan (LPDP) KEMENKEU RI for giving the author the opportunity to study Masters in UPI and finish this research for seminar in ADVERD 2017. Thank you to Laboratory Primary School UPI Cibiru as a place to share knowledge.

\section{REFERENCE LIST}

Bhargava, D. R. (2016). Effect of Concept Attainment Model on Achievement in Social Sciences. International Journal of Science and Research (IJSR), 5(5).

Bill, V. dan Jamar, I. (2010)." Diciplinary Literacy in Mathematics Classroom" dalam Conten Matters : A Disciplinary Literaxy Approach to Improving Student Learning. San Fransisco : Jossey-Bass A wiley Imprint.

Concannon-Gibney, T. \& McCarthy, M.J.(2012). "The Explicit Teaching of Reading Comprehension in Science Class: a Pilot Professional Development Program". Improving Schools. 15 (1).

Ivanic, R. (2009). "Bringing Literacy Studies into Research and Prospects" dalam The Future of Literacy Studies. New York: Palgrave MacMillan.

Joyce, B., Weil, M., \& Calhoun, E. (2009). Models of Teaching: Model-Model Pengajaran (Edisi 8). Yogyakarta: Pustaka Pelajar.

McConachi, S.M., et al. (2010). Content Matters: A Disciplinary Literacy Approach to Improving Student Learning. San Fransisco : Jossey-Bass A Wiley Imprint.

McKee, J. dan Ogle, D. (2005). Interesting Instruction Literacy and Science. New York : The Guilford Press.

Morocco, C.C. et al. (2008). Supported Literacy for Adolescents : Transforming Teaching and Content Learning for $21^{\text {st }}$ century. San Fransisco : Jossey-Bass A wiley Imprint.

NCTM. (2000). Principles and Standars for School Mathematics. [Online]. Accesed : www.nctm.org. 10 Maret 2017.

NCTM (2012). Principles and Standars for School Mathematics Volume 1. Michigan : National Council of Teachers of Mathematics.

Olge, D. Et al. (2007). Buliding Literacy in Social Studies : Strategies for Improving Comprehension and Critical Thinking. Alexandria : ASCD.

Pusat Penilaian Badan Penelitian dan Pengembangan (2017). Hasil TIMSS 2015. Accesed : www.acdpindonesia.org/wp-content/uploads/2017/01/TIMSS-infographic.pdf

Shyyan, et al (2008). Instructional Strategies for Improving Achievement in Reading, Mathematics, and Science for English Languange Learners. Assesment for Effective Intervention. 33 (3).

Siregar, E. and Nara, H. (2010). Teori Belajar dan Pembelajaran. Bogor: Ghalia Indonesia.

Suwangsih, E. and Tiurlina. (2010) Model pembelajaran matematika. Bandung: UPI PRESS.

Swidler, L. (2014). Dialogue Institute: "Whole Child Education" Exercise in Concept Attainment Dialogue for Interreligious Understanding.

Trilling, B. \& Fadel, C. (2009), $21^{\text {st }}$ Century skills. San Fransisco : Jossey-Bass A wiley Imprint. 